\title{
Virucidal activity of chlorhexidine on strains of Herpesvirus hominis, poliovirus, and adenovirus
}

\author{
ANDREW BAILEY AND MAURICE LONGSON \\ From the Department of Bacteriology and Virology, University of Manchester
}

SYNOPSIS The infectivity titre of two strains of Herpesvirus hominis was reduced by not more than six $\log _{10}$ units by 90 minutes' exposure to chlorhexidine at a final concentration of $0.02 \%$ at room temperature. Under identical conditions the compound was ineffective against a vaccine strain of poliovirus and against an adenovirus. Experimental conditions are described whereby the toxic effect of the disinfectant on the tissue culture assay systems are minimized.

Primary infection with Herpesvirus hominis is increasingly frequent in young adult and adult populations (Smith, Peutherer, and MacCallum, 1967; Davies and Longson, 1970) and there is evidence that, under certain conditions, such infections may be associated with severe and very distressing disease (Montgomerie, Becroft, Croxon, Doak, and North, 1969; Lynch and Longson, 1970; Longson, 1970). A recent suggestion that inadequate sterilization of clinical thermometers may cause cross infection with Herpesvirus hominis appeared to merit attention. It is common hospital practice to disinfect clinical thermometers by inmersion in $0.02 \%$ chlorhexidine solution and the present study was designed to study the sensitivity of the virus to this disinfectant.

\section{Materials}

TISSUE CULTURE CELLS AND MEDIA

All media were prepared from dried powders obtained commercially (Wellcome Reagents Ltd); these were supplemented with locally obtained bovine serum and with penicillin and streptomycin. H.Ep 2 cells (Flow Laboratories Ltd) had been serially cultivated in this laboratory for two years. Growth medium consisted of Eagle's MEM and $10 \%$ calf serum. $\mathrm{RK}_{13}$ cells, kindly supplied by $\mathrm{Dr} \mathrm{J}$. O'H. Tobin, were grown on medium 199 supplemented with $5 \%$ foetal calf serum. In both cases reduced serum concentrations $(2.5 \%)$ were used for cell maintenance.

EGGS

Fertile white-shelled eggs were obtained locally and

Received for publication 4 June 1971. were kept at $38^{\circ} \mathrm{C}$, in an automatic egg incubator for 11 days before use.

VIRUS STOCKS

Herpesvirus hominis (HVH), oral strain SUE (Herpesvirus h simplex-1), and genital strain MVC 70 (Herpesvirus h simplex-2) (Hutfield and Longson, 1968) were grown in monolayer cultures of $\mathrm{RK}_{13}$ cells. Suspensions of infected cells in tissue culture media were stored in ampoules at $-170^{\circ} \mathrm{C}$ (liquid nitrogen) until required (Bailey, 1970).

Poliovirus, type 2 (Sabin) (Enterovirus h polio-2/ Sabin) was obtained from a vial of monovalent vaccine and cultivated in cultures of rhesus monkey kidney cells. The virus suspension was stored at $-20^{\circ} \mathrm{C}$ until required.

Adenovirus, type 2 (Adenovirus h-2), originally isolated in this laboratory from a throat swab, was cultivated in H.Ep 2 cells and stored at $-20^{\circ} \mathrm{C}$.

The identity of all stock virus suspensions was confirmed by neutralization against standard specific antisera, kindly supplied for this purpose by $\mathrm{Dr}$ C. M. P. Bradstreet.

CHLORHEXIDINE

The stock solution of chlorhexidine consisted of $5 \% \mathrm{w} / \mathrm{v}$ chlorhexidine gluconate (Hibitane $\left.{ }^{1}, \mathrm{ICI}\right)$ in water.

\section{Method and Results}

All tissue culture experiments were performed on conventional monolayer cultures in $13 \times 1.2 \mathrm{~cm}$

${ }^{1}$ Hibitane also contains $3.75 \%$ Lissapol. Experiments at present in hand suggest that Herpesvirus hominis may also be sensitive to this surface active agent. 
neutral glass tubes. Before inoculation confluent cell sheets were washed free of growth medium and fed with $0.9 \mathrm{ml}$ of maintenance medium per tube. After inoculation with fluid under test the cultures were incubated in a sloping position at $33.5^{\circ} \mathrm{C}$ and examined daily.

Eggs were candled, drilled, and inoculated on the chorioallantoic membrane in the usual manner (Beveridge and Burnet, 1946). After inoculation eggs were maintained in a stationary incubator at $36.5^{\circ} \mathrm{C}$ for 72 hours. The membranes were harvested and fixed in $10 \%$ formol saline before examination.

\section{CYTOTOXICITY OF CHLORHEXIDINE}

The disinfectant.stock solution was diluted $1 / 1 \cdot 25$ and then in ten-fold steps from $4 \times 10^{-2}$ to $4 \times 10^{-8}$ $(40,000$ to $0.04 \mu \mathrm{g} / \mathrm{ml})$ in sterile phosphate-buffered saline $p H$ 7.2 (PBS, Oxoid). Tubes of H.Ep 2 cells were inoculated in triplicate with $0.1 \mathrm{ml}$ of each of these dilutions, incubated, and observed for seven days. It was observed that at concentrations in excess of $0.004 \mu \mathrm{g} / \mathrm{ml}$ chlorhexidine was toxic to the cells.

In a second experiment, therefore, the chlorhexidine solutions were inoculated into tissue cultures in the same way but the tubes were incubated at $37^{\circ} \mathrm{C}$ for 90 minutes, when the cultures were washed free of disinfectant by three changes of phosphate-buffered saline. Fresh, chlorhexidine-free maintenance medium was then added to each culture and the tubes were returned to the incubator for seven days as before. Under these conditions no toxic effects were observed, even at concentrations as high as $4,000 \mu \mathrm{g} / \mathrm{ml}$ chlorhexidine.

To test the toxicity of the disinfectant on the chorioallantoic membrane of the chick, $0.2 \mathrm{ml}$ of each of a series of tenfold dilutions containing from $40,000 \mu \mathrm{g} / \mathrm{ml}$ to $0.04 \mu \mathrm{g} / \mathrm{ml}$ of chlorhexidine was inoculated into four 10-day-old eggs, which were incubated at $35.5^{\circ} \mathrm{C}$ for 72 hours. Careful examina- tion of the harvested membranes and of the embryos failed to reveal any toxicity of the chlorhexidine.

EFFECT OF CHLORHEXIDINE ON SENSITIVITY OF TISSUE CULTURE CELLS

Triplicate tubes of H.Ep 2 cells and of $\mathrm{RK}_{13}$ cells were exposed for 90 minutes at $37^{\circ} \mathrm{C}$ to varying concentrations of chlorhexidine ranging from $4,000 \mu \mathrm{g} / \mathrm{ml}$ to $0.004 \mu \mathrm{g} / \mathrm{ml}$ (final concentration in the medium). After washing with three changes of PBS, the cultures were challenged with $0.1 \mathrm{ml}$ of a suspension containing $10 \mathrm{TCID}_{50} / 0 \cdot 1 \mathrm{ml}$ of Herpesvirus hominis. The virus was allowed to adsorb for 90 minutes at $37^{\circ} \mathrm{C}$, when the residual inoculum was washed off by a further three changes of phosphatebuffered saline. After replacement of the maintenance medium the tubes were incubated and examined as previously described. In comparison to controls, and within the crude limits of these experiments, all the disinfectant-treated cultures appeared fully sensitive to the small dose of virus.

\section{VIRUCIDAL ACTIVITY OF CHLORHEXIDINE}

Equal volumes $(0.5 \mathrm{ml})$ of stock virus suspensions and of chlorhexidine solution diluted in PBS to contain $400 \mu \mathrm{g} / \mathrm{ml}$ were mixed and kept at room temperature (final concentration of chlorhexidine $200 \mu \mathrm{g} / \mathrm{ml})$. Controls consisted of equal volumes of virus and phosphate-buffered saline. After 90 minutes the mixtures were diluted in tenfold steps in further PBS, and surviving virus was assayed by the inoculation of $0.2 \mathrm{ml}$ of virus/disinfectant mixture and end-point titration in H.Ep 2 cells, using four tubes per dilution. In the case of Herpesvirus hominis similar assays were carried out on cultures of $R_{K_{13}}$ cells and on the chorioallantoic membrane of the chick.

The effect of chlorhexidine on the infectivity of two strains of Herpesvirus hominis, one strain of adenovirus, and one strain of poliovirus was investigated

\begin{tabular}{|c|c|c|c|c|}
\hline \multirow[t]{3}{*}{ Virus } & \multicolumn{4}{|c|}{ Surviving Virus } \\
\hline & \multicolumn{2}{|l|}{$P B S^{1}$} & \multicolumn{2}{|c|}{$0.02 \%$ Chlorhexidine ${ }^{1}$} \\
\hline & $T C I D_{50} / m^{2}$ & $P F U / m l^{3}$ & $T C I D_{\mathrm{so}} / \mathrm{ml}^{2}$ & $P F U / m l^{3}$ \\
\hline $\begin{array}{l}\text { HSV (MVC 70) } \\
\text { HSV (SUE) } \\
\text { Polio (Sabin/2) } \\
\text { Adeno (type 2) }\end{array}$ & $\begin{array}{l}3 \times 10^{6} \\
1 \times 10^{4} \\
3 \times 10^{7} \\
1 \times 10^{4}\end{array}$ & $\begin{array}{l}2 \times 10^{5} \\
1.2 \times 10^{5} \\
-\end{array}$ & $\begin{array}{l}<1 \\
<1 \\
3 \times 10^{7} \\
4 \times 10^{4}\end{array}$ & $\begin{array}{l}<1 \\
<1 \\
=\end{array}$ \\
\hline
\end{tabular}

Table Virucidal activity of chlorhexidine

'Virus surviving after exposure of stock virus suspension (in tissue culture medium containing $2 \cdot 5 \%$ serum) to effect of either PBS or chlor hexidine gluconate $0.02 \% \mathrm{w} / \mathrm{v}$ final concentration. See text.

Tissue culture infectious doses calculated after Kärber (1931).

Pock-forming units on chick chorioallantoic membrane. 
on at least three occasions each. The results of one such series of assays are shown in Table I. Almost identical titres were obtained in all replicate experiments.

All assay tubes which remained persistently negative were challenged on the seventh day by the inoculation of $10 \mathrm{TCID}_{50}$ of the appropriate virus. After this challenge all the previously negative cultures produced typical cytopathic effects, confirming that the chlorhexidine had not appreciably affected the sensitivity of the cells.

\section{Discussion}

There is a surprising lack of information on the sensitivity of Herpesvirus hominis to common disinfectants. Early work by Levaditi and Harvier (1920) suggested that the virus was resistant to $1 \%$ phenol. This was later confirmed by Sery and Furgiuele (1961) but refuted by Klein and Deforest (1963). According to Klein and Deforest (1965), Herpesvirus hominis is highly sensitive to sodium hypochlorite, formaldehyde, and glutaraldehyde. The virus is also destroyed by quaternary ammonium compounds and by $\beta$ propriolactone (Tokumaru and Scott, 1964).

Chlorhexidine (Hibitane, Nolvasan, Sterilon) is an excellent antiseptic but is not generally considered to be a reliable virucidal substance and its use is not advised for this purpose (Finter, 1970). Indeed, earlier work (Hurst, 1955) had indicated that Herpesvirus hominis is resistant to chlorhexidine. Nevertheless, Eppley, Hays, and Kucera (1968) recommended the agent as a virucidal disinfectant for veterinary use. These workers reported that under experimental conditions a number of viruses were sensitive to $0.05 \%$ chlorhexidine. In particular, the herpes virus of infectious bovine rhinotracheitis, similar in size, morphology, and composition to Herpesvirus hominis, lost 5-6 $\log _{10}$ units of infectivity after 10 minutes' exposure at room temperature. The present results confirm these findings and it is interesting to contrast the marked resistance of an enterovirus and an adenovirus to the disinfectant under identical experimental conditions. Whereas Herpesvirus hominis lost 5-6 log units of infectivity, ie, almost $100 \%$, the two non-enveloped viruses remained fully active.

The kinetics of the virus inactivation by the chlorhexidine remain to be established and it is very likely that total killing of the virus would be possible, even by prolonged contact. The detection of the stable viral residuum may be difficult and will depend, in some measure, on the sensitivity of the assay system. To this end $\mathrm{RK}_{13}$ cells were also used because of their sensitivity to Herpesvirus hominis. Even greater sensitivity could perhaps have been obtained by the use of larger inocula or by virus concentration techniques.
In the meantime the results obtained in these experiments justify the use of chlorhexidine as a disinfectant in the medical and in the veterinary prophylaxis of herpetic infections. In particular, there is no reason to believe that the 'sterilization' of clinical thermometers in the compound may lead to crossinfections with Herpesvirus hominis and, perhaps, the use of chlorhexidine cream in burned patients could prevent herpetic superinfection (British Medical Journal, 1970). Whether the compound could be used in the therapeutic management of established herpes dermatitis or of dendritic ulcers is worthy of investigation. However, the activity of chlorhexidine on intracellular virus might be difficult to study because of its marked cytotoxic effect. It may, on the other hand, be fruitful to investigate the value of a solution in the treatment of experimental herpetic keratitis in the rabbit.

We wish to thank Professor T. S. L. Beswick in whose laboratory the work was performed for helpful advice and encouragement.

\section{References}

Bailey, A. (1970). Unpublished observations.

Beveridge, W. I. B., and Burnet, F. M. (1946). The cultivation of viruses and rickettsiae in the chick embryo. Med. Res. Coun. (Lond.), Spec. Rep. Ser., 256.

British Medical Journal (1970). Herpesvirus infection in burned patients (Leading Article). Brit. med. J., 2, 618-619.

Davies, R. M., and Longson, M. (1970). Herpetic infection in adults: acute gingivostomatitis and associated traumatic herpes. Oral Surg., 30, 41-47.

Eppley, J. R., Hays, M. B., and Kucera, C. J. (1968). Nolvasan: a virucide. Biochem. Rev., 33, 9-13.

Finter, N. B. (1970). Personal communication.

Hurst, E. W. (1955). Results on file. Imperial Chemical Industries, Macclesfield, England.

Hutfield, D. C., and Longson, M. (1968). Infection of the vulva and cervix with a genital strain of herpes simplex virus. J. Obstet. Gynaec. Brit. Cwlth, 75, 768-774.

Karber, G. (1931). Beitrag zur kollecktiven Behandlung pharmakologisher Reihenversuche. Arch. Path. Pharmakol., 162, 480-483.

Klein, M., and Deforest, A. (1963). The inactivation of viruses by germicides. In Proceedings of the 49th Mid-Year Meeting of C.S.M.A., pp. 116-118.

Klein, M., and Deforest, A. (1965). The chemical inactivation of viruses. (Abstr.) Fed. Proc., 24, 319.

Levaditi, C., and Harvier, P. (1920). Le virus de l'encéphalite léthargique (encéphalite épidémique). C.R. Soc. Biol. (Paris), 83, 354-355.

Longson, M. (1970). Studies with the virus of Herpes simplex. MD Thesis, University of Manchester.

Lynch, P., and Longson, M. (1970). Herpes simplex encephalitis. In VIth International Congress of Neuropathology, pp. 1162-1163. Masson, Paris.

Montgomerie, J. Z., Becroft, D. M. O., Croxson, M., Doak, P. B. and North, J. D. K. (1969). Herpes-simplex-virus infection after renal transplantation. Lancet, 2, 867-871.

Sery, T. W., and Furgiıele, F. P. (1961). The inactivation of herpessimplex virus by chemical agents. Amer. J. Opthal., 51, 42-57.

Smith, I. W., Peutherer, J. F., and MacCallum, F. O. (1967). The incidence of Herpesvirus hominis antibody in the population. J. Hyg. (Lond.), 65, 395-408.

Tokumaru, T., and Scott, T. F. M. (1964). In Diagnostic Procedures for Viral and Rickettsial Diseases, 3rd ed., edited by E. H. Lennette and N. S. Schmidt, pp. 400-401. American Public Health Association, New York. 